\title{
ANALISA ROI DENGAN PENDEKATAN DU PONT DALAM MENILAI KINERJA KEUANGAN PT. MUSTIKA RATU, TBK DSN PT. MARTINA BERTO TAHUN 2010 - 2016
}

\author{
Selvia Nuriasari, M.E.I \\ IAIN METRO \\ selviasari7@gmail.com
}

\begin{abstract}
Abstrak
Rasio Profitabilitas adalh rasio yang melihat kemampuan perusahaan menghasilkan laba, salah satu rasionya adalah rasio ROI du pont. Tujuannya adalah agar mampu melihat lebih detail tentang penyebab kenaikan atau penurunan dari ROI itu sendiri. PT. Mustika Ratu, Tbk dan PT. Martina Berto adalah dua perusahaan nasional yang bergerak di sektor industri manufaktur yang kondisi ekonomi perusahaan tersebut mengalami penurunan yang disebabkan antara lain masuknya produkproduk dari luar negeri. Tentunya ini akan berdampak pada penurunan penjualan dan ada indikasi persediaan yang menumpuk akibat dari turunnya penjualan.Profitability Ratio is the ratio that sees the company's ability to generate profit, one of which is the ratio of ROI du pont. The goal is to be able to see more detail about the cause of the increase or decrease of the ROI itself. PT. Mustika Ratu, Tbk and PT. Martina Berto is two national companies engaged in the manufacturing industry that the company's economic conditions experienced a decrease caused by the entry of products - products from abroad. Surely this will have an impact on sales declines and there are indications of inventories that accumulate as a result of declining sales.
\end{abstract}

Kata kunci : Profitabilitas, ROI du pont, kinerja keuangan

\begin{abstract}
Profitability Ratio is the ratio that sees the company's ability to generate profit, one of which is the ratio of ROI du pont. The goal is to be able to see more detail about the cause of the increase or decrease of the ROI itself. PT. Mustika Ratu, Tbk and PT. Martina Berto is two national companies engaged in the manufacturing industry that the company's economic conditions experienced a decrease caused by the entry of products - products from abroad. Surely this will have an impact on the decline in sales and there are indications of inventory that accumulate as a result of the decline of sales.Profitability Ratio is the ratio that sees the company's ability to generate profit, one of which is the ratio of ROI du pont. The goal is to be able to get more detail about the cause of the increase or decrease of the ROI itself. PT. Mustika Ratu, Tbk and PT. Martina Berto is two national companies engaged in the manufacturing industry. Surely this will have an impact on sales declining sales.
\end{abstract}

Keywords: Profitability, ROI du pont, financial performance

\section{PENDAHULUAN}

Rasio Profitabilitas adalah rasio yang melihat kemamuan perusahaan menghasilkan laba dan bagaimana perusahaan memanfaat aktiva dalam menghasilakan laba secara efektif serta bagaimana perusahaan mengelola bebena - beban usaha dan beban non usaha sehingga mampu menghasilakn laba yang tinggi atau sesuai dengan target intinya rasio profitabilitas ini melihat seberapa mampukah perusahaan mengelola investasi perusahaan dalam menghasilkan keuntungan bagi perusahaan. Tolak ukur dalam melihat kesehatan rasio 
profitabilitas ini adalah semakin tinggi hasil rasio, maka semakin sehat. Dalam menganalisa rasio profitabilitas, data yang digunakan adalah laporan keuangan terutama laporan laba rugi dan laporan neraca. Ada berbagai macam rumus dari rasio profitabilitas seperti rasio Margin laba kotor, rasio margin laba bersih, rasio margin laba operasi, rasio margin arus kas, rasio Pengembalian kas atas aktiva, rasio ROI, ROI $d u$ pont, rasio ROE, rasio pertumbuhan penjualan, rasio EPS dan rasio EOPS. Salah satu rasio yang cukup sering digunakan adalah rasio $\mathrm{ROI} d u$ pont.

ROI $d u$ pont adalah pengembangan dari rasio ROI yaitu rasio yang melihat kemampuan perusahaan dalam mengembalikan investasi. ROI du pont menggunakan dua rumus dari dua rasio yang berbeda, yaitu rasio profitabilitas dan rasio aktivitas. Tujuannya ROI $d u$ pont adalah agar mampu melihat lebih detail tentang penyebab kenaikan atau penurunan dari ROI itu sendiri dengan menggunakan dua rasio keuangan yang saling berhubungan. Adapun rumus - rumus yang akan digunakan dalam menganalisa rasio ROI du pont adalah Margin laba laba dan perputaran total aktiva. PT. Mustika Ratu, Tbk dan PT. Martina Berto adalah dua perusahaan nasional yang bergerak di sektor industri pembuatan jamu, kosmetik dan bahan-bahan untuk perawatan kecantikan, kondisi ekonomi perusahaan tersebut mengalami penurunan yang disebabkan antara lain semakin banyaknya perusahaan pesaing dan masuknya produk - produk dari luar negeri dengan harga yang lebih murah seperti dari Negara Cina. Tentunya ini akan berdampak secara langsung pada penurunan penjualan dan ada indikasi persediaan yang menumpuk akibat dari turunnya penjualan. Hal ini diperkuat dari berita pada tahun 2018, yaitu sebagai berikut:

"Selain masalah distribusi, masuknya produk-produk kecantikan dari Cina juga membuat konsumen mulai berpaling untuk mencoba produk asal Negeri Panda.Kenaikan harga bahan bakar minyak, upah minimum provinsi, dan melemahnya rupiah, juga turut menghambat Mustika Ratu. "Melemahnya nilai rupiah hingga Rp 12.128 per dolar Amerika Serikat pada 2013, berdampak signifikan bagi perseroan, terutama untuk pengadaan bahan baku impor, " 1

Berdasarkan hal tersebut diatas, ada dua hal yang menjadi perhatian peneliti yaitu turunnya penjualan akibat dari produk luar negeri terutama dari Negara China.Kemudian pada kuarta I, mustika ratu mengumumkan kerugian perusahaan kosmetik tersebut, yang diakibatkan turunnya penjualan, naiknya biaya keuangan dan selisih kurs yang mengalami

1 Tempo.co. tanggal :11 Juni 2014. Alamat :https://bisnis.tempo.co/read/584236/penjualan$\underline{\text { mustika-ratu-terkendala-distribusi }}$ 
kenaikan, sebagaimana dikutip dalam $\underline{w w w . b i s n i s . c o m}$ yaitu sebagai berikut $:^{2}$

Bisnis.com, JAKARTA - Laba bersih emiten kosmetik PT Mustika Ratu Tbk. (MRAT) sepanjang kuartal I/2016 turun tajam 82,77\%.Berdasarkan laporan keuangan kuartal I/2016 yang dipublikasikan Selasa (3/5/2016), laba bersih yang dapat diatribusikan kepada pemilik entitas induk perseroan tercatat sekitar Rp272,19 juta. Laba tersebut anjlok 82,77\% dibandingkan dengan perolehan laba kuartal I/2015 yang mencapai Rp1,58 miliar. Turunnya laba bersih perseroan seiring dengan penurunan penjualan bisnis perseroan. Penjualan MRAT tercatat Rp81,44 miliar pada kuartal I/2016 atau turun 17,47\% dibandingkan periode yang sama sebelumnya senilai Rp98,68 miliar. Bila diperinci, terlihat penjualan kosmetik turun 17,82\% menjadi Rp100,37 miliar. Penjualan jamu juga turun menjadi Rp10,72 miliar dari sebelumnya Rp11,35 miliar. Sementara itu, penjualan minuman kesehatan 17,9\% dari Rp733,46 juta menjadi Rp864,61 juta pada kuartal I/2016. Penurunan laba bersih juga didorong oleh rugi selisih kurs yang dialami perseroan hingga Rp1,34 miliar. Sementara pada periode yang sama tahun lalu, perseroan mencatat laba dari selisih kurs Rp403,10 juta. Biaya keuangan juga naik menjadi Rp831,05 juta dari Rp693,70 juta. Selisih kurs karena penjabaran laporan keuangan juga naik 247,90\% menjadi Rp1,77 miliar dari Rp510,42 juta.

\section{KERANGKA TEORI}

\section{Margin Laba Bersih}

Rasio laba kotor atau margin laba kotor adalah perbandingan antara laba kotor dengan penjualan.Laba kotor penrupakan idnikator awal mengenai pencapatain laba perusahaan.Jarangs ekali perusahaan gagal pada tingkat laba kotor.Apabila perusahaan mendapatkan laba kotor negative, peluang untuk memperioleh laba usaha sudah tidak ada.Jadi apabila perusahaan gagal disini maka secara fundamental bisnisnya merugi. ${ }^{3}$ Adapun rumusnya adalah sebagai berikut :

$$
\text { Rasio NPM }=\frac{\text { laba Kotor }}{\text { penjualan bersih }}
$$

Rasio NPM menurut Kasmir, adalah rasio yang melihat kemampuan perusahaan dalam menghasilkan laba bersih (EAIT) dibandingkand engan penjualan dimana rata - rata industry dari rasio GPM ini adalah minimal 20\% dapat dikatakan sehat atau profit. ${ }^{4}$

\section{Perputaran Total Aktiva}

Rasio perputaran aktiva ini melihat sejauh mana asset secara keseluruhan berputar

\footnotetext{
${ }^{2}$ http://market.bisnis.com/read/20160503/192/544090/kinerja-mrat-penjualan-kosmetik-danjamu-turun-laba-mustika-ratu-anjlok
}

${ }^{3}$ Toto Prihadi. Analisis Laporan keuangan : Teori Dan Aplikasi (PPM : Jakarta :2011), hal. 140

${ }^{4}$ Kasmir.Analisa Laporan Keuangan. (Jakarta : PT. Raja Grafindo Persada, 2008), hal. 200 
secara efektif untuk menghasilkan penjualan.Standar industrinya minimal 2 kali dalam satu periode. Adapun rumusnya adalah :

$$
\text { Rasio perputaran aktiva }=\frac{\text { penjwalan bersih }}{\text { aset bersih }}
$$

\section{ROI $d u$ pont}

Adapun rumus ROI du pont adalah NPM dikalikan dengan perputaran total aktiva dimana rata - rata industrinya adalah minimal $40 \%$.

\section{Kinerja Keuangan Perusahaan ${ }^{5}$}

Untuk memutuskan suatu badan usaha atau suatu eprusahaan memiliki kualitas yang baik maka ada dua penilaian yang paling dominan yang dapat dijadikan acuan untuk melihat badan usaha / perusahaan tersebut menjalankan suatu kaidah - kaidah manajemen yang baik. Penilaian ini dapat dilakukan dengan melihat sisi kinerja keuangan dan kinerja non keuangan. Kinerja keuangan melihat pada laporan keuangan yang dimiliki badan usaha / perushaan yang bersangkutan dan itu tercermin dari informasi yang diperoleh dari neraca, laporan laba rugi dan laporan arus kas serta hal - hal lain yang turut mendukung sebagai penguat penilaian kinerja keuangan tersebut. Rasio keuangan adalah salah satu alat yang digunakan dalam mengukur kinerja keuangan perusahaan tersebut.

\section{Kajian Pustaka}

1. Yuni Nustini, Analisis Dupont Untuk Mengukur Competitive Advantage Perusahaan Pengaplikasi Teknologi Informasi. Jurnal Sinergi : Kajian Bisnis dan Manajemen vol. 6 No. 1 tahun 2003, hal. 31-46, ISSN : 1410-9018. Saat ini teknologi informasi (TI) termasuk di dalamnya intranet, extranet dan internet telah memunculkan cara berbisnis baru yaitu e-commerce yang selanjutnya memperluas fungsinya menjadi e-business. TI tidak hanya merubah cara orang bekerja (the way people work), tetapi juga merubah cara perusahaan bersaing (the way business compete). Beberapa penelitian telah dilakukan untuk mengukur keberhasilan implementasi aplikasi TI pada perusahaan. Hasilnya mengatakan, perusahaanperusahaan pengimplementasi TI memiliki financial performance yang lebih unggul bila dibandingkan dengan pesaingnya. Penelitian ini bertujuan untuk memberikan bukti empiris mengenai terdapat tidaknya hubungan antara aplikasi TI dengan kinerja keuangan perusahaan

\footnotetext{
${ }^{5}$ Irham Fahmi, Analisa Laporan keuangan. ( Bandung : Alfabeta, 2014) hal 134
} 
pengaplikasi TI (pengaplikasi e-business) di Indonesia. Financial performance diukur dengan menggunakan ROA DuPont karena rasio ini dapat mengukur tingkat pengembalian investasi. Hasil penelian ini menunjukkan kenyataan yang berbeda secara substansial dari penelian-penelitian pendahulunya yang dilakukan di Amerika Serikat, yaitu ditemukan tidak adanya hubungan antara aplikasi TI dalam suatu perusahaan dengan kinerja keuangannya. Perusahaan dengan peringkat yang tinggi sebagai pengimplementasi ebusiness belum tentu memiliki peringkat yang tinggi pada financial performancenya. Hasil ini memberikan bukti empiris, bahwa aplikasi TI oleh perusahaan-perusahaan di Indonesia belum bisa diandalkan untuk meraih competitive advantage sehingga superior financial performance tidak dapat dicapai, tidak seperti yang terjadi di banyak perusahaan di AS. ${ }^{6}$

2. Evi Ziadatul Nikmah, M. Saifi dan A. Husaini. Analisis Rasio Keuangan Dalam Du Pont System Sebagai Dasar Untuk Mengukur Kinerja Keuangan Perusahaan (Studi Pada PT. Nippon Indosari Corpindo, Tbk Yang Terdaftar Pada BEI Periode 2010 - 2012).jurnal Administrasi Bisnis Unibraw, vol.6, no 1 tahun 2013. Penggunaan analisis rasio keuangan ini bertujuan untuk mengetahui keadaan suatu perusahaan yang dilakukan dengan cara mengukur kinerja keuangan perusahaan. Selain itu Du Pont System juga salah satu cara untuk mengukur kinerja keuangan perusahaan. Du Pont System merupakan salah satu teknik analisa keuangan yang sifatnya menyeluruh, manajemen bisa mengetahui tingkat efisiensi penggunaan model, efisiensi bagian produksi dan efisiensi bagian penjualan. Perusahaan yang terpilih sebagai penelitian adalah PT. Nippon Indosari Corpindo, Tbk. Hasil kinerja keuangan perusahaan yang diperoleh dari tahun ke tahun mengalami perubahan, yang mana perubahan itu terjadi kenaikan dan penurunan. Perubahan tersebut menandakan bahwa kinerja keuangan perusahaan dari tahun ke tahun masih belum menunjukkan keadaan positif. Perusahaan sebaiknya mengetahui kinerja agar kedepannya perusahaan menjadi lebih baik lagi dari tahun sebelumnya dan laba yang dicapai juga akan maksimal. 7

Berdasarkan dua penelitain diatas maka dapat diketahui bahwa penelitian yang peneliti lakukan belum ada yang meneliti meskipun sama-sama menggunakan ROI $d u$ pont.

${ }^{6}$ https://media.neliti.com/media/publications/86528-ID-analisis-dupont-untuk-mengukurcompetiti.pdf

${ }^{7}$ http://administrasibisnis.studentjournal.ub.ac.id/index.php/jab/article/view/256/449 
6 | Selvia Nuriasari

\section{PEMBAHASAN}

\section{Profil PT. Mustika Ratu, Tbk dan PT. Martina Berto, Tbk}

\section{a. Sejarah Singkat PT. Mustika Ratu, Tbk $^{8}$}

Mustika Ratu Tbk (ㅁRAT) didirikan 14 Maret 1978 dan mulai beroperasi secara komersial pada tahun 1978.Kantor pusat MRAT berlokasi di Graha Mustika Ratu, Penthouse Floor, Jalan Gatot Subroto Kav. 74-75, Jakarta Selatan kode pos 12870 - Indonesia dan pabrik berlokasi di Jalan Raya Bogor KM. 26,4 Ciracas, Jakarta Timur kode pos 13740. Pemegang saham yang memiliki 5\% atau lebih saham Mustika Ratu Tbk, yaitu: PT Mustika Ratu Investama (pengendali) (71,26\%) dan Mellon S/A Investors Pacific International, Jakarta (8,91\%). Berdasarkan Anggaran Dasar Perusahaan, ruang lingkup kegiatan MRAT meliputi pabrikasi, perdagangan dan distribusi jamu dan kosmetik tradisional serta minuman sehat, perawatan kecantikan, serta kegiatan usaha lain yang terkait. Merek yang dimiliki MRAT,yaitu : Mustika Ratu, Mustika Puteri, Bask, Biocell, Moor's, Ratu Mas, Taman Sari Royal Heritage Spa. Pada tanggal 28 Juni 1995, MRAT memperoleh pernyataan efektif dari Bapepam-LK untuk melakukan Penawaran Umum Perdana Saham MRAT (IPO) kepada masyarakat sebanyak 27.000.000 dengan nilai nominal Rp500,- per saham dengan harga penawaran Rp2.600,- per saham. Saham-saham tersebut dicatatkan pada Bursa Efek Indonesia (BEI) pada tanggal 27 Juli 1995. Berikut ringkasan data dari PT. Mustika Ratu, Tbk atau dengan kode di BEI yaitu:

Tabel 1.a : Profil PT. Mustika Ratu, Tbk ${ }^{9}$

\begin{tabular}{|ll|}
\hline Nama & $:$ Mustika Ratu Tbk \\
Kode & $:$ MRAT \\
Alamat Kantor & $:$ Graha Mustika Ratu Lt PH Jl Gatot Subroto Kav 74-75 Jakarta \\
Alamat Email & $:$ info@mustika-ratu.co.id \\
No. Telepon & $:$ 021-8306754,8306759, 8307419 \\
Faks & $:$ 021-830-6753, 830-6760 \\
& $\begin{array}{l}{ }^{8} \underline{\text { http://britama.com/index.php/2012/12/sejarah-dan-profil-singkat-mrat/ }} \\
\text { 9http://www.idx.co.id/id-id/beranda/perusahaantercatat/profilperusahaantercatat.aspx }\end{array}$
\end{tabular}


7 | Selvia Nuriasari

\begin{tabular}{|ll|} 
NPWP & $: 01.002 .915 .5-054.000$ \\
Situs & $: 0$ \\
Tanggal IPO & $:$ http://www.mustika-ratu.com/ \\
\hline \hline Papan & $:$ UTAMA \\
Bidang Usaha & $:$ Industri Kosmetika \\
Utama & $:$ CONSUMER GOODS INDUSTRY \\
Sektor & $:$ COSMETICS AND HOUSEHOLD \\
Sub Sektor & $:$ PT. Datindo Entrycom \\
Biro Administrasi & \\
\hline Efek & \\
\hline
\end{tabular}

Sekretaris Korporat

\begin{tabular}{|l|l|l|}
\hline \multicolumn{1}{|c|}{ Nama } & \multicolumn{1}{|c|}{ Email } & \multicolumn{1}{c|}{ No. Telepon } \\
\hline $\begin{array}{l}\text { Boma Kharista. S., S.E., } \\
\text { Ak }\end{array}$ & $\begin{array}{l}\text { info@mustika- } \\
\text { ratu.co.id }\end{array}$ & (021) 830-6754, 830-6759 \\
\hline
\end{tabular}

\section{Direktur}

\begin{tabular}{|l|l|c|}
\hline \multicolumn{1}{|c|}{ Nama Direktur } & \multicolumn{1}{|c|}{ Jabatan Direktur } & Terafiliasi \\
\hline Putri K. Wardani & DIREKTUR UTAMA & Yes \\
\hline Dewi Nur Handayani & DIREKTUR & Yes \\
\hline Arman S. Tjitrosoebono & DIREKTUR & Yes \\
\hline - & DIREKTUR & Yes \\
\hline Komisaris & \multicolumn{1}{|c|}{ Jabatan Komisaris } & Independen \\
\hline Haryo T. Baskoro & PRESIDEN KOMISARIS & No \\
\hline F. G. Winarno & KOMISARIS & Yes \\
\hline Darodjatun Sanusi & KOMISARIS & No \\
\hline
\end{tabular}

Komite Audit

Nama Komite Audit

Jabatan Komite Audit

Prof. DR. F. G. Winarno

Ketua (Komisaris Independen)

Jurnal Hukum dan Ekonomi Syari'ah, Vol. 06 | Nomor 5 


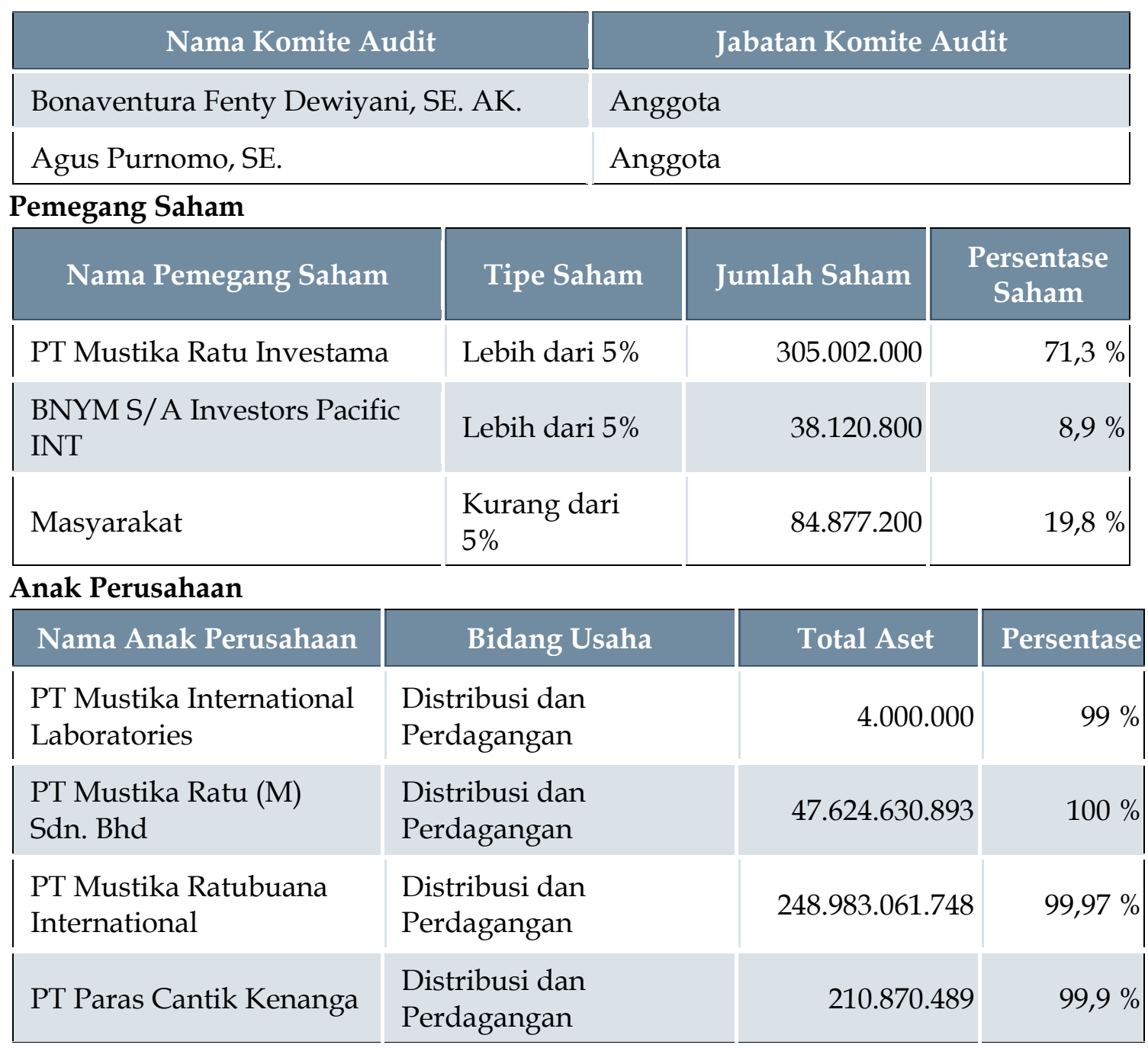

\section{b. Sejarah Singkat PT. MARTINA BERTO, Tbk10}

Dr.HC.MarthaTilaar mengawali usaha dengan membuka salon kecantikan pada tahun 1970. Selain itu beliau terus menimba ilmu tentang kecantikan dan perawatan tubuh ke pusat kecantikan di Amerika dan Eropa. Hal inilah yang membangkitkan semangat dan kesadaran beliau bahwa bahan baku yang berasal dari Indonesia jika diolah dengan baik dan professional dapat menghasilkan kosmetika alami dan jamu tradisional yang dapat mempercantik wanita Indonesia dan dunia secara holistic. Setelah sukses dalam bisnis salon kecantikan dengan beberapa salon di Jakarta, Ibu Martha Tilaar mendirikan sekolah kecantikan Puspita Martha yang mencetak ahli kecantikan, penata rias, penata rambut dan terapis. Salon dan sekolah tersebut dioperasikan dibawah bendera PT Martha Beauty

${ }^{10}$ Laporan Tahunan BRI

Jurnal Hukum dan Ekonomi Syari'ah, Vol. 06 | Nomor 5 
Gallery. Kesuksesan tersebut mendorong Ibu Martha Tilaar memulai untuk memproduksi kosmetika dan jamu dan mendirikan PT Martina Berto pada tanggal 1 Juni 1977 dengan mitra usaha yaitu Bapak Bernard Pranata (alm) dan Ibu Theresia Harsini Setiady.

Merk pertama yang diproduksi dan dipasarkan adalah "Sari Ayu Martha Tilaar" sebagai kosmetika alami yang berkonsepholistik, dengan laboratorium praktek di salon dan sekolah kecantikan tersebut. Hal ini menyebabkan produk- produk Sari Ayu Martha Tilaar selalu berkiblat kepada pendidikan dan layanan konsumen yang praktis dan mudah diterapkan. Sambutan pasar yang tinggi maka pada tanggal 22 Desember 1981 menyebabkan perusahaan ini mendirikan pabrik modern yang pertama PT Martina Berto di Jl. Pulo Ayang, Kawasan Industri Pulo Gadung, JakartaTimur. Dengan berjalannya waktu, pabrik kekurangan kapasitas produksi, kemudian pada tahun 1986 didirikan pabrik ke dua di Jl. Pulokambing II/1, Kawasan Industri Pulo Gadung dengan konsentrasi pada kosmetika kering,semi padat dan jamu sedangkan pabrik yang pertama dikonsentrasikan pada produk kosmetika cair.

Pada periode 1988-1994 Perseroan melahirkan merek- merek kosmetika baru seperti Cempaka, Martina, Pesona, Biokos Martha Tilaar, Caring Colours Martha Tilaar dan Belia Martha Tilaar untuk mengantisipasi permintaan pasar yang meningkat. Produk-produk ini telah membantu menyerap kapasitas pabrik cukup besar. Perubahan strategis berikutnya setelah tahun 2000 adalah penataan ulang atas merek-merek, yang terbagi dalam 2 kelompok, yaitu: merek-merek yang berlabel "Martha Tilaar"dengan lisensi dari Dr. (HC) Martha Tilaar dan keluarga, dan merek-merek yang tetap menjadi hak intelektual Perseroan seperti“Cempaka”dan“Pesona”. Periode 1993 - 1995 Perseroan mengakuisisi beberapa anak perusahaan yang bergerak di bidang kosmetik, yaitu PT Cedefindo (CDF), PT Kurnia Harapan Raya (KHR) dan PT Estrella Laboratories(Estrella).

Untuk mencapai efisiensi produksi pada periode 1995 - 1996 Perseroan melakukan proses restrukturisasi usaha dan relokasi pabrik. Perkembangan strategis berikutnya dalam periode 2001 - 2009 antara lain, pemetaan ulang merek-merek di segmen yang berbeda yang akan dibahas di babtersendiri. Pada tahun 2016, Perseroan membeli merek Rudy Hadisuwarno untuk kategori kosmetika dan perawatan tubuh. Adapun Kegiatan usaha utama Perseroan yaitu sebagai berikut :

1) Memproduksi barang-barang kosmetika dan obat tradisional (jamu). 
2) Pemasaran, perdagangan barang kosmetik, perawatan kecantikan dan obat tradisional.

3) Selain itu, Perseroan memiliki kegiatan usaha penunjang yang dilakukan oleh anak perusahaan yaitu :

a) PT Cedefindo, yaitu: jasa produksi atau makloon dalam produk kosmetika kering, semi padat, cair dan aerosol, termasuk jasa formulasi, registrasi, pengadaan bahan baku/kemas, proses produksi, pengemasan sampai logistik secara one stop service bagi internal Martha Tilaar Group maupun ekstenal dari perusahaan-perusahaan lainnya. Cedefindo berdomisili di Bekasi dan berkedudukan di Graha Cedefindo, Jl, Raya Narogong km.4, Bekasi Timur17116.

b) EasternBeautypelagoPteLimited(“EB”),yaitu : anak perusahaan yang berkedudukan di Singapore yang dibentuk untuk mengembangkan pasar ekspor Perseroan serta mengelola dan mengembangkan Martha Tilaar Shop (MTS) yaitu unit retaid milik Perseroan di luar negeri. EB berdomisili di Singapore dan beralamat di 1 Rafles Place \#44-02, Singapore 048616.

Berikut ini ringkasan sejarah PT. Martina Berto dari awal berdiri hingga tahun 2016 yaitu sebagai berikut :

1) 1977 : Mulai beroperasi dengan peluncuran Sariayu sebagai merek dari salon sendiri.

2) 1981 : Di tahun 1981 Perseroan membangun pabrik pertamanya dijl .Pulo Ayang no. 3, Kawasan Industri Pulo Gadung, dengan merek Sariayu Martha Tilaar.

3) 1986 : Di tahun 1986 Perseroan membangun pabrik modern kedua di jl. Pulo kambing II no.1 , Kawasan Industri Pulo Gadung ("Pabrik PuloKambing”).

4) 1993 : Di tahun 1993 Perseroan mengakuisisi PT. Cedefindo yang bisnis utamanya adalah kontrak manufaktur untuk produkkosmetika.

5) 1995 : Di 1995, merelokasi fasilitas herbal Punung Putri dan dipindahkan ke pabrik Pulo Ayang menjadi kepada PT.CempakaBelkosindoIndah(“CBI” / anak perusahaan ) serta memproduksi merek Mirabella \& Cempaka.

6) 1999 : Perseroan dikuasai sepenuhnya oleh keluarga Martha Tilaar setelah melewati krisis moneter.

7) 2005 : Digabung dengan PT. CBIdan dan mengalihkan produksi merek Mirabella dan Cempaka ke pabrik Pulo Kambing.

8) 2010 : Meluncurkan gerai Martha Tilaar (MTS), di luar negeri untuk meraih pangsa pasar internasional.

9) 2011 : Penawaran umum perdana saham Perseroan di Bursa Indonesia. Dengan Initial 
Public Ouering of MBTO shares in IDX

10) 2012 : Peletakkan batu pertama konstruksi pabrik baru herbal/obat tradisional di Kampoeng Djamoe Organik (KaDO), Cikarang.

11) 2013 : PT. Martina Berto, Tbk Membangun fasilitas produksi botol kemasan di pabrik Pulo Ayang.

12) 2016 : Membeli merek Rudy Hadisuwarno (kategori kosmetik dan perawatan tubuh).

2. Analisa Rasio Dori Du Pont Pt. Mustika Ratu, Tbkdan Pt. Martina Berto, Tbk, (Tahun 2010 - 2016)

\section{a. Rasio NPM}

Adapun rumus NPM adalah sebagai berikut :

$$
\text { Rasio NPM }=\frac{\text { laba Kotor }}{\text { penjualan bersih }}
$$

Berikut ini adalah hasil perhitungan dari rasio NPM atau rasio margin laba bersih dari dua perusahaan tersebut :

Table 2.a :Hasil Perhitungan Rasio Margin Laba Bersih (NPM)

PT. Mustika Ratu, Tbk tahun 2010 - 2016 (dalam bentuk rupiah)

\begin{tabular}{|c|c|c|c|c|c|}
\hline RASIO & & & & & \\
\hline PROFITABILITAS & 2009 & 2010 & 2011 & 2012 & RI \\
\hline EAT & Rp.21,016,846,720 & Rp.24,418,796,930 & Rp.27,867,834,532 & Rp.30,751,407,882 & \\
\hline PENJUALAN & Rp.345,575,853,364 & Rp.369,366,074,883 & Rp.406,315,784,681 & Rp.458,197,338,824 & \\
\hline NPM & $6.08 \%$ & $6.61 \%$ & $6.86 \%$ & $6.71 \%$ & $20 \%$ \\
\hline
\end{tabular}

Table 2.b :Hasil Perhitungan Rasio Margin Laba Bersih (NPM)

PT. Mustika Ratu, Tbk tahun 2010 - 2016 (dalam bentuk rupiah)

\begin{tabular}{|lcccc|}
\hline \multicolumn{1}{|c}{ RASIO } & & & & \\
PROFITABILITAS & 2,013 & 2,014 & 2,015 & 2,016 \\
\hline EAT & Rp. $(6,700,373,076)$ & Rp. $7,054,710,411$ & Rp. $1,045,990,311$ & Rp. $(5,549,465,678)$ \\
PENJUALAN & Rp.358,127,545,503 & Rp. $434,747,101,600$ & Rp. $428,092,732,505$ & Rp.344,361,345,265 \\
\hline NPM & $-1.87 \%$ & $1.62 \%$ & $0.24 \%$ & $-1.61 \%$ \\
\hline
\end{tabular}

Berdasarkan hasil perhitungan diatas, diketahui bahwa rasio net profit margin atau margin laba bersih PT. Mustiak Ratu, Tbkk tahun 2010 sampai tahun 2016 tidak sehat atau dibawah rata - rata industru atau in-profit. Hal ini diakibatkan EAT atau laba bersih nya mengalami penurunan yang signifikan bahkan mengalami rugi bersih yaitu tahun 2013 sebesar Rp. $(6,700,373,076)$ dan tahun 2016 sebesar Rp. $(5,549,465,678)$.

Penurunan EAT atau EAIT atau laba setelah dipotong beban bunga dan beban pajak tahun 2016 ini diakibatkan oleh: turunnya penjualan tahun 2016 dibandingkan penjualan Jurnal Hukum dan Ekonomi Syari'ah, Vol. 06 | Nomor 5 
tahun 2015 yaitu dari Rp. 428,092,732, 505,- ke Rp. 344,361,345,265 yang berdampak pada turunnya laba kotor, naiknya beban keuangan yaitu dari Rp. 3,665,411,293,- Ke Rp. 4,747,208,360,- ; dan naiknya kerugian dari selisih kurs yaitu dari Rp. $(266,342,637,-)$ Ke Rp. $(1,309,954,850,-)$.

Table 2.c :Hasil Perhitungan Rasio Margin Laba Bersih

PT. MARTINA BERTO, Tbk (tahun 2010 - 2016)

\begin{tabular}{|lrrrr|}
\hline \multicolumn{1}{|c}{ PROFITABILITAS } & \multicolumn{2}{c}{2009} & \multicolumn{1}{c}{2011} & 2012 \\
\hline EAT & Rp.22,230,134,344 & Rp.36,764,116,491 & Rp.42,659,406,355 & Rp.45,523,078,819 \\
PENJUALAN & Rp.516,318,810,609 & Rp.566,186,416,236 & Rp.648,375,230,795 & Rp.717,788,399,047 \\
NPM & $4.31 \%$ & $113.90 \%$ & $6.58 \%$ & $6.34 \%$ \\
\hline
\end{tabular}

Table 2.d. :Hasil Perhitungan Rasio Margin Laba Bersih

PT. MARTINA BERTO, Tbk (tahun 2010 - 2016)

\begin{tabular}{|lrrrrr|}
\hline PROFITABILITAS & \multicolumn{2}{c}{2013} & \multicolumn{1}{c}{2014} & 2015 & RI \\
\hline & & & & & \\
EAT & Rp.16,162,858,075 & $R p .4,209,673,280$ & Rp. $(14,056,549,894)$ & Rp.8,813,611,079 \\
PENJUALAN & Rp.641,284,586,295 & Rp.671,398,849,823 & Rp.694,782,752,351 & Rp.685,443,920,925 \\
NPM & $2.52 \%$ & $0.63 \%$ & $-2.02 \%$ & $1.29 \%$ & $20 \%$ \\
\hline
\end{tabular}

Berdasarkan hasil perhitungan diatas, diketahui bahwa rasio net profit margin atau margin laba bersih PT. Martina Berto, Tbk tahun 2010 sampai tahun 2016 tidak sehat atau dibawah rata - rata industru atau in-profit, kecuali tahun 2010 dalam kondisi profit. Kondisi in profit ini diakibatkan karna EAT atau laba bersih nya cenderung mengalami penurunan yang signifikan bahkan mengalami rugi bersih yaitu tahun 2015 sebesar Rp. (14,056,549,894).

\section{b. Rasio Perputaran Total Aktiva}

Table 2.e :Rasio Perputaran Aktiva Tetap Mustika Ratu Tahun 2010 - 2016

\begin{tabular}{|lccccc|}
\hline RASIO AKTIVITAS & 2009 & 2010 & 2011 & 2012 & RI \\
\hline & & & & & \\
PENJUALAN BERSIH & $R p .345,575,853,364$ & $R p .369,366,074,883$ & $R p .406,315,784,681$ & Rp.458,197,338,824 \\
ASET & $R p .365,635,717,933$ & $R p .386,352,442,915$ & $R p .422,493,037,089$ & Rp.455,472,778,210 \\
\hline PERPUTARAN AKTIVA & $\mathbf{0 . 9 5}$ & $\mathbf{0 . 9 6}$ & $\mathbf{0 . 9 6}$ & $\mathbf{1 . 0 1}$ \\
\hline
\end{tabular}

Table 2.f :Rasio Perputaran Aktiva Tetap Mustika Ratu Tahun 2010 - 2016

\begin{tabular}{|lcccc|}
\hline RASIO AKTIVITAS & 2013 & 2014 & 2015 & 2016 \\
\hline PENJUALAN BERSIH & & & Rp.428,092,732,505 &
\end{tabular}




\begin{tabular}{|lcrrr|} 
& Rp.358,127,545,503 & Rp.434,747,101,600 & \multicolumn{2}{c|}{ Rp.344,361,345,265 } \\
\multirow{2}{*}{ ASET } & Rp.439,583,727,200 & Rp.500,138,658,228 & Rp.497,090,038,108 & Rp.483,037,173,864 \\
\hline PERPUTARAN AKTIVA & $\mathbf{0 . 8 1}$ & $\mathbf{0 . 8 7}$ & $\mathbf{0 . 8 6}$ & $\mathbf{0 . 7 1}$ \\
\hline
\end{tabular}

Sama dengan rasio perputaran aktiva tetap, rasio perutaran aktiva juga bertujuan untuk melihat kemampuan perusahaan mengelola aktiva yang dimiliki perusahaan dalam menghasilkan laba melalui aktivitas penjualannya.Artinya, jika semakin cepat perputarannya maka perusahaan semakin mampu mengelola aktiva baik aktiva lancer maupun aktiva tidak lancar. Rasio ini juga memiliki tujuan untuk melihat kinerja manajemen dalam kebijakan mengelola ativa, apakah mampu mendukung aktivitas operasi demi meningkatkan penjualan sehingga laba meningkat atau tidak.Semakin cepat perputarannya, maka semakin baik perusahaan atau semakin efektif perusahana dalam mengelola aktiva yang dimiliki perusahaan untuk menghasilkan laba dengan meningkatkan penjualan dengan standar minimal 5 kali dalam satu periode dikatakan efektif atau sehat.

Berdasarkan rasio diatas, maka dapat diketahui bahwa rasio Perputaran aktiva mengalami penurunan dan dibawah rata - rata industry yang artinya tidak sehat atau inefektif yaitu dibawah 2 kali berputar dalam setahun. Berdasarkan data diatas, maka perputaran aktiva terhadap penjualan dari tahun 2010 sampai tahun 2016 semakin turun dan in - efektif, dimana penurunan terendah adalah pada tahun 2016 yaitu sebesar 0,71 kali perputarannya dalam setahun. Maka dapat dikatakan manajemen kurang mampu mengelola seluruh aktiva dalam meningkatkan penjualan.

Table 2.g. :Rasio Perputaran Aktiva Tetap Martina Berto Tahun 2010 - 2016

\begin{tabular}{|lccccc|}
\hline & 2009 & 2010 & 2011 & 2012 \\
\hline PENJUALAN BERSIH & Rp.516,318,810,609 & Rp.566,186,416,236 & Rp.648,375,230,795 & Rp.717,788,399,047 \\
ASET & Rp.276,872,269,613 & Rp.333,129,929,836 & Rp.541,673,841,000 & Rp.609,494,013,942 \\
PERPUTARAN AKTIVA & 1.86 & 1.70 & 1.20 & 1.18 \\
\hline
\end{tabular}

Table 2.g. :Rasio Perputaran Aktiva Tetap Martina Berto Tahun 2010 - 2016

\begin{tabular}{|lccccc|}
\hline & 2013 & 2014 & 2015 & 2016 \\
\hline PENJUALAN BERSIH & Rp.358,127,545,503 & Rp.434,747,101,600 & Rp.428,092,732,505 & Rp.344,361,345,265 \\
ASET & Rp.439,583,727,200 & Rp.498,786,376,745 & Rp.648,899,377,240 & Rp.709,959,168,088 \\
PERPUTARAN AKTIVA & 0.81 & 0.87 & 0.66 & 0.49 & $\geq 2$ X \\
\hline
\end{tabular}

Rasio perutaran aktiva bertujuan untuk melihat kemampuan perusahaan mengelola Jurnal Hukum dan Ekonomi Syari'ah, Vol. 06 | Nomor 5 
aktiva yang dimiliki perusahaan dalam menghasilkan laba melalui aktivitas penjualannya.Artinya, jika semakin cepat perputarannya maka perusahaan semakin mampu mengelola aktiva baik aktiva lancer maupun aktiva tidak lancar. Rasio ini juga memiliki tujuan untuk melihat kinerja manajemen dalam kebijakan mengelola ativa, apakah mampu mendukung aktivitas operasi demi meningkatkan penjualan sehingga laba meningkat atau tidak.Semakin cepat perputarannya, maka semakin baik perusahaan atau semakin efektif perusahana dalam mengelola aktiva yang dimiliki perusahaan untuk menghasilkan laba dengan meningkatkan penjualan dengan standar minimal 5 kali dalam satu periode dikatakan efektif atau sehat.

Berdasarkan rasio diatas, maka dapat diketahui bahwa rasio Perputaran aktiva mengalami penurunan dan dibawah rata - rata industry yang artinya tidak sehat atau inefektif yaitu dibawah 2 kali berputar dalam setahun. Berdasarkan data diatas, maka perputaran aktiva terhadap penjualan dari tahun 2010 sampai tahun 2016 semakin turun dan in - efektif, dimana penurunan terendah adalah pada tahun 2016 yaitu sebesar 0,49 kali perputarannya dalam setahun yang diakibatkan turunnya penjualan dan naikny aset. Maka dapat dikatakan manajemen kurang mampu mengelola seluruh aktiva dalam meningkatkan penjualan. Jika dilihat, maka rasio perputaran aktiva Matina Berto dan Mustika ratu sama sama mengalami penurunan dan tidak sehat pada tahun 2016, tetapi penurunan yang tertinggi adalah pada perusahaan Mustika ratu

\section{c. Rasio Roi Du Pont}

Berdasarkan rasio du pont bahwa rasio du pont memadukan dua rumus dari rasio yang berbeda dengan tujuan untuk melihat lebih jelas penyebab kenaikan atau penurunan dari ROI itu sendiri.Rata - rata industrinya minmal $30 \%$ dapat dikatakan sehat.Adapun rumusnya adalah :

ROI du pont $=$ NPM $\times$ perputaran aktiva

Table 2.h :Rasio ROI Du Pont Mustika Ratu Tahun 2010 - 2016

\begin{tabular}{|lcccc|}
\hline TAHUN & 2009 & 2010 & 2011 & 2012 \\
\hline EAT & Rp.21,016,846,720 & Rp.24,418,796,930 & Rp.27,867,834,532 & Rp.30,751,407,882 \\
PENJUALAN & Rp.345,575,853,364 & Rp.369,366,074,883 & Rp.406,315,784,681 & Rp.406,315,784,681 \\
NPM & $6.08 \%$ & $6.61 \%$ & $6.86 \%$ & $7.57 \%$ \\
\hline PENJUALAN BERSIH & Rp.345,575,853,364 & Rp.369,366,074,883 & Rp.406,315,784,681 & Rp.458,197,338,824
\end{tabular}


15 | Selvia Nuriasari

\begin{tabular}{|lcccc|} 
ASET & Rp.365,635,717,933 & Rp.386,352,442,915 & Rp.422,493,037,089 & Rp.455,472,778,210 \\
PERPUTARAN AKTIVA & 0.95 & 0.96 & 0.96 & 1.01 \\
\hline ROI DU PONT & $5.75 \%$ & $6.32 \%$ & $6.60 \%$ & $7.61 \%$ \\
\hline
\end{tabular}

Table 2.i :Rasio ROI Du Pont Mustika Ratu Tahun 2010 - 2016

\begin{tabular}{|c|c|c|c|c|}
\hline TAHUN & 2013 & 2014 & 2015 & 2016 \\
\hline EAT & Rp. $(6,700,373,076)$ & Rp.7,054,710,411 & Rp.1,045,990,311 & Rp. $(5,549,465,678)$ \\
\hline PENJUALAN & Rp.358,127,545,503 & Rp.434,747,101,600 & Rp.428,092,732,505 & Rp.344,361,345,265 \\
\hline NPM & $-1,87 \%$ & $1,62 \%$ & $0,24 \%$ & $-1,61 \%$ \\
\hline PENJUALAN BERSIH & Rp.358,127,545,503 & Rp.434,747,101,600 & Rp.428,092,732,505 & Rp.344,361,345,265 \\
\hline ASET & Rp.439,583,727,200 & Rp.500,138,658,228 & Rp.497,090,038,108 & Rp. $483,037,173,864$ \\
\hline PERPUTARAN AKTIVA & 0.81 & 0.87 & 0.86 & 0.71 \\
\hline ROI DU PONT & $-1.34 \%$ & $1.51 \%$ & $0.22 \%$ & $-0.97 \%$ \\
\hline
\end{tabular}

Berdasarkan hasil diatas, maka di ketahui bahwa ROI du pont Mustika Ratu in-profit dan menurun dimana hal ini disebabkan oleh turunnya penjualan dan laba bersih bahkan pada tahun 2016, Mustika Ratu mencetak rugi bersih. Selain itu juga perputaran aktiva nya di bawah rata - rata industry dimana aktiva mengalami kenaikan sedangkan penjualan mengalami penurunan maka ada indikasi bahwa ada asset yang belum dimanfaatkan secara optimal untuk meningkatkan penjualan.

Table 2.j :Rasio ROI Du Pont Martina Berto, Tbk. Tahun 2010 - 2016

\begin{tabular}{|c|c|c|c|c|}
\hline TAHUN & 2009 & 2010 & 2011 & 2012 \\
\hline PENJUALAN BERSIH & Rp.516,318,810,609 & Rp.566,186,416,236 & Rp.648,375,230,795 & Rp.717,788,399,047 \\
\hline ASET & Rp.276,872,269,613 & Rp.333,129,929,836 & Rp.541,673,841,000 & Rp.609,494,013,942 \\
\hline PERPUTARAN AKTIVA & 1.86 & 1.70 & 1.20 & 1.18 \\
\hline EAT & Rp.22,230,134,344 & Rp.36,764,116,491 & Rp.42,659,406,355 & Rp.45,523,078,819 \\
\hline PENJUALAN & Rp.516,318,810,609 & Rp.566,186,416,236 & Rp.648,375,230,795 & Rp.717,788,399,047 \\
\hline NPM & $4.31 \%$ & $6.49 \%$ & $6.58 \%$ & $6.34 \%$ \\
\hline ROI DU PONT & $8.03 \%$ & $11.04 \%$ & $7.88 \%$ & $7.47 \%$ \\
\hline TAHUN & 2013 & 2014 & 2015 & 2016 \\
\hline PENJUALAN BERSIH & Rp.358,127,545,503 & Rp.434,747,101,600 & Rp.428,092,732,505 & Rp.344,361,345,265 \\
\hline ASET & Rp.439,583,727,200 & Rp.498,786,376,745 & Rp. $648,899,377,240$ & Rp.709,959,168,088 \\
\hline PERPUTARAN AKTIVA & 0.81 & 0.87 & 0.66 & 0.49 \\
\hline EAT & Rp.16,162,858,075 & Rp.2,925,070,199 & Rp.-14,056,549,894 & Rp.8,813,611,079 \\
\hline PENJUALAN & Rp.358,127,545,503 & Rp.434,747,101,600 & Rp.428,092,732,505 & Rp.344,361,345,265 \\
\hline
\end{tabular}




\begin{tabular}{lllll} 
NPM & $4.51 \%$ & $0.67 \%$ & $-3.28 \%$ & $2.56 \%$ \\
ROI DU PONT & $3.68 \%$ & $0.59 \%$ & $-2.17 \%$ & $1.24 \%$ \\
\hline
\end{tabular}

Berdasarkan hasil diatas, maka di ketahui bahwa ROI du pont Martina Berto in-profit dan menurun dimana hal ini disebabkan oleh turunnya penjualan dan turunnya laba bersih yang sangat signifikan bahkan pada tahun 2015, Martina Berto mengalami rugi bersih.Selain itu juga perputaran aktiva nya di bawah rata - rata industry dimana aktiva mengalami kenaikan sedangkan penjualan mengalami penurunan maka ada indikasi bahwa ada asset yang belum dimanfaatkan secara optimal untuk meningkatkan penjualan. Kondisi keuangan kedua perusahaan ini sama - sama mengalami in-profit dan semakin turun yang diakibatkan penjualan turun yang berdampak pada laba bersih turun.

\section{KESIMPULAN}

Berdasarkan perhitungan diatas, maka dapat disimpulkan bahwa rasio ROI du pont PT. Mustika Ratu, Tbk. Dan Martina Berto, Tbk Tahun 2010-2016 yaitu sebagai berikut :

Berdasarkan hasil diatas, maka di ketahui bahwa ROI du pont Mustika Ratu in-profit dan menurun dimana hal ini disebabkan oleh turunnya penjualan dan laba bersih bahkan pada tahun 2016, Mustika Ratu mencetak rugi bersih.Selain itu juga perputaran aktiva nya di bawah rata - rata industry dimana aktiva mengalami kenaikan sedangkan penjualan mengalami penurunan maka ada indikasi bahwa ada asset yang belum dimanfaatkan secara optimal untuk meningkatkan penjualan.

Berdasarkan hasil diatas, maka di ketahui bahwa ROI du pont Martina Berto in-profit dan menurun dimana hal ini disebabkan oleh turunnya penjualan dan turunnya laba bersih yang sangat signifikan bahkan pada tahun 2015, Martina Berto mengalami rugi bersih.Selain itu juga perputaran aktiva nya di bawah rata - rata industry dimana aktiva mengalami kenaikan sedangkan penjualan mengalami penurunan maka ada indikasi bahwa ada asset yang belum dimanfaatkan secara optimal untuk meningkatkan penjualan.

Kondisi keuangan kedua perusahaan ini sama - sama mengalami in-profit dan semakin turun yang diakibatkan penjualan turun yang berdampak pada laba bersih turun. 


\section{DAFTAR PUSTAKA}

Evi Ziadatul Nikmah, Muhammad Saifi dan Achmad Husaini. Analisis Rasio Keuangan Dalam Du Pont System Sebagai Dasar Untuk Mengukur Kinerja Keuangan Perusahaan (Studi Pada Pt. Nippon Indosari Corpindo, Tbk Yang Terdaftar Pada Bei Periode 2010 - 2012). Jurnal Administrasi Bisnis Vol. 6 no. 1 tahun 2013. Alamat : http://administrasibisnis.studentjournal.ub.ac.id/index.php/jab/article/view/256/449

http:// britama.com/index.php/2012/12/sejarah-dan-profil-singkat-mrat/

http://www.idx.co.id/id-id/beranda/perusahaantercatat/profilperusahaantercatat.aspx

Irham Fahmi. 2014. Analisa Laporan keuangan. Bandung. Alfabeta.

Kasmir. 2008. Analisa Laporan Keuangan. Jakarta. PT. Raja Grafindo Persada.

Persiana Galih. Penjualan Mustika Ratu Terkendala Distribusi. Tanggal : 11 Juni 2014. Alamat : https:// bisnis.tempo.co/read/584236/penjualan-mustika-ratu-terkendala-distribusi

Riendy Astria. Penjualan Kosmetik dan Jamu Turun, Laba Mustika Ratu Anjlok. Tanggal : 3 Mei 2016. Alamat : http://market.bisnis.com/read/20160503/192/544090/kinerja-mrat-penjualankosmetik-dan-jamu-turun-laba-mustika-ratu-anjlok

Toto Prihadi. 2011. Analisis Laporan keuangan : Teori Dan Aplikasi. PPM. Jakarta.

Yuni Nustiti. Analisis Dupont untuk Mengukur Competitive Advantage perusahaan Pengaplikasi Teknologi Informasi. Jurnal Sinergi : Kajian Bisnis dan Manajemen Vol. 6 No. 1 tahun 2003. Hal 31 - 46. alamat: https://media.neliti.com/media/publications/86528-ID-analisis-dupontuntuk-mengukur-competiti.pdf 